\title{
Pedon Characterization in the Caatinga Biome Area in Chapada Apodi, RN, Brazil
}

\author{
Francisca Elisângela Maniçoba ${ }^{1}$, Francisco Gonçalo Filho ${ }^{2}$, Lunara G. da S. Rêgo ${ }^{2}$, Carolina M. M. Souza ${ }^{3}$, \\ Ana Carla Rodrigues da Silva ${ }^{4}$, Rebeca Nairony da Silva Lima ${ }^{2}$, Miguel Ferreira Neto ${ }^{3} \&$ Neyton de O. Miranda ${ }^{3}$ \\ ${ }^{1}$ Phytotechnics Graduate Program, Universidade Federal Rural do Semi-Árido, Mossoró, Brazil \\ ${ }^{2}$ Graduate Program in Soil and Water Management, Universidade Federal Rural do Semi-Árido, Mossoró, Brazil \\ ${ }^{3}$ Center of Agrarian Sciences, Universidade Federal Rural do Semi-Árido, Mossoró, Brazil \\ ${ }^{4}$ Agronomist Engineer, Brazil
}

Correspondence: Lunara G. da S. Rêgo, Programa de Pós Graduação em Manejo de Solo e Água, Universidade Federal Rural do Semi-Árido, R. Francisco Mota, 572-Pres. Costa e Silva, Mossoró, RN, 59625-900, Brazil. Tel: 55-84-98883-9506. E-mail: lunaragleika@hotmail.com

Received: February 12, $2020 \quad$ Accepted: June 17, $2020 \quad$ Online Published: August 15, 2020

doi:10.5539/jas.v12n9p138 URL: https://doi.org/10.5539/jas.v12n9p138

The research is financed by Universidade Federal Rural do Semi-Árido.

\begin{abstract}
The Apodi Plateau is a Brazilian with important agricultural activity, which is located between the states of Ceará and Rio Grande do Norte, in an area of the Caatinga biome. Therefore, this work was developed to characterize the morphological, physical, chemical and mineralogical attributes of soil profiles of this region. For this purpose, trenches were open in three areas in the Tabuleiro Grande Settlement Project, in the municipality of Apodi, RN, Brazil. The profiles were described in the field and samples of the horizons were collected for physical, chemical and mineralogical analyzes. The profiles were classified up to the fourth categorical level and correlated with Soil Taxonomy.According to the Brazilian Soil Classification System, the soils studied were Vertissolo Háplico Órtico chernossólico (Mollisols), Chernossolo Rêndzico Petrocálcico típico (Mollisols) e Vertissolo Háplico Órtico chernossólico (Vertisols).
\end{abstract}

Keywords: pedology, soil classification, limestone, semiarid climate

\section{Introduction}

The Caatinga biome occupies most of the Northeast of Brazil with an area of approximately $844,453 \mathrm{~km}^{2}$, encompassing the states of Piaui, Ceará, Rio Grande do Norte, Paraiba, Pernambuco, Sergipe, Bahia, Maranhão and northern Minas Gerais (MMA, 2019). This ecosystem is formed by a vast biodiversity, presenting unique fauna and flora, being one of the most threatened biomes in Brazil due to the inadequate and unsustainable use of its soils and natural resources.

The lands of the Caatinga areas are of crystalline and sedimentary origin. In the sedimentary area is found the Apodi Plateau in Rio Grande do Norte, inserted in the geological context "Aracati Platform", which is the emerged portion of the "Potiguar Sedimentary Basin", characterized by a package of transgressive river-marine sediments that is represented locally by the Formations Açu, Quebradas and Jandaíra (Pessoa Neto et al., 2007). The soils of Chapada do Apodi originate from the fine-grained fossiliferous limestone, belonging to the Apodi Group, referring to the Cretaceous.

According to generic soil surveys (Ernesto Sobrinho, 1979), on the north side of the Apodi Plateau predominate more clayey and eutrophic soils. The soils that stand out are Inceptisols, with high primary mineral content and presence of Bi horizon due to incipient weathering (Marques, Souza, Souza, Lima, \& Souza Júnior, 2014); Chernosols, which have higher organic matter content on the surface horizon, high base saturation, high clay activity and presence of 2:1 clay minerals; and Vertisols, which have higher clay content and small textural variation along the profile, as well as expandable clays that cause volume increase with increasing soil water content and cracks in the dry season (Santos et al., 2018). 
According to Sekhar, Naidu, Ramprakash, and Balaguravaiah (2019), soil is non-renewable and finite natural resource, undergoing degradation at preoccupying levels due to indiscriminate use and lack of adequate management. For its best management are necessary Soil Survey investigations that point its limitations and potentialities. For this, the first step is soil characterization and classification. In this context, there is no sufficient information about soils occurring at the Apodi Plateau. Hence, the present study aims to characterize morphological, physical, chemical and mineralogical attributes, and classify soils in Caatinga biome area of the Apodi Plateau, Rio Grande do Norte, Brazil.

\section{Method}

The area under study belongs to the Tabuleiro Grande Settlement Project, located in the municipality of Apodi, Midwest of the state of Rio Grande do Norte $\left(5^{\circ} 24^{\prime} 33.33^{\prime \prime} \mathrm{S}\right.$ and $\left.37^{\circ} 46^{\prime} 40^{\prime \prime} \mathrm{W}\right)$, with medium elevation of 109 meters. It is inserted in the Chapada do Apodi microregion, predominantly represented by the limestones of the Jandaíra Formation at the top and the sandstones of the Açu Formation, located at the base (Pessoa Neto et al., 2007).

The predominant climate of the region is of the BSh type (dry semiarid, with annual potential evapotranspiration greater than annual precipitation), according to the Köppen classification. Average annual rainfall ranges from 380 to $760 \mathrm{~mm}$, with a general average of $600 \mathrm{~mm}$; the average annual air temperature is $28^{\circ} \mathrm{C}$ and the average annual relative humidity is approximately $65 \%$ (Alvarez, Stape, Sentelhas, Gonçalves, \& Spavorek, 2013). The local vegetation is of the hyperxerophilous Caatinga type, associated with secondary forest formations with varied herbaceous substrate, whose native plant diversity is represented basically by Caesalpinia bracteosa Tul., Aspidorperma pyrifolium Mart., Croton argyrophylloides Mull. Arg., Croton blanchetianus Baill, Combretum leprosum Mart., Mimosa caesalpiniifolia Benth, and Auxemma oncocalyx (Fr. All.) Baill.

The definition of the studied areas and the opening of profiles were based on reconnaissance expeditions throughout the area of the Tabuleiro Grande Settlement Project and the observation of the most representative pedoforms of the region. Thus, three locations for trench opening were selected (Table 1).

The morphological descriptions and sample collection of the profiles were performed according to the recommendations of Santos, Lemos, Santos, Ker, Anjos, and Shimizu (2015). The soil samples collected in each horizon were air dried, grinded and sieved with a $2 \mathrm{~mm}$ mesh opening, obtaining the air-dried fine earth (ADFE) to perform the physical, chemical and mineralogical analyzes in each horizon of profiles.

The nomenclature of the diagnostic horizons and the taxonomic classification of soils up to the 4th categorical level were made according to the Brazilian Soil Classification System (Santos et al., 2018).

Table 1. Location of soil profiles described in the Caatinga biome area at the Apodi Plateau, Brazil

\begin{tabular}{llll}
\hline Profile & Latitude & Longitude & Elevation \\
\hline Profile 1 (P1) & $5^{\circ} 3^{\prime} 39.8^{\prime \prime} \mathrm{S}$ & $37^{\circ} 23^{\prime} 44.6^{\prime \prime} \mathrm{W}$ & $78 \mathrm{~m}$ \\
Profile 2 (P2) & $5^{\circ} 3^{\prime} 37.7^{\prime \prime} \mathrm{S}$ & $37^{\circ} 24^{\prime} 15.4^{\prime \prime} \mathrm{W}$ & $90 \mathrm{~m}$ \\
Profile 3 (P3) & $5^{\circ} 3^{\prime} 58.5^{\prime \prime} \mathrm{S}$ & $37^{\circ} 24^{\prime} 3.2^{\prime \prime} \mathrm{W}$ & $76 \mathrm{~m}$ \\
\hline
\end{tabular}

Physical and chemical analyzes were performed with three repetitions, according to methods described by (Teixeira, Donagema, Fontana, \& Teixeira, 2017). In addition to the particle size analysis by the pipette method, the following characteristics were determined: $\mathrm{pH}$ in water; electrical conductivity (EC), measured in soil-water solution with conductivity meter; available phosphorus extracted by Mehlich-1 solution and determined by spectrophotometry; exchangeable potassium and sodium cations, extracted with Mehlich-1 solution, and calcium and magnesium extracted with $\mathrm{KCl}$ solution $1 \mathrm{~mol} \mathrm{~L}^{-1}$; exchangeable aluminum $\left(\mathrm{Al}^{3+}\right)$ extracted by the $\mathrm{KCl}$ solution $1 \mathrm{~mol} \mathrm{~L}^{-1}$; potential acidity $(\mathrm{H}+\mathrm{Al})$ extracted with calcium acetate solution $0.5 \mathrm{~mol} \mathrm{~L}^{-1}$. Total organic carbon (TOC) was determined using the method proposed by Yeomans \& Bremner (1988), determined by the oxidation of organic matter by potassium dichromate. From the analyzes performed the following indexes were obtained: cation exchange capacity at $\mathrm{pH} 7.0(\mathrm{~T})$; base saturation $(\mathrm{V})$, exchangeable aluminum saturation $(\mathrm{m})$ and exchangeable sodium percentage (ESP).

For the mineralogical characterization, the ADFE was used from the diagnostic horizons of each soil profile, which were ground to powder. The identification of the mineral phases was performed by X-ray diffraction (XRD), using a SHIMADZU diffractometer, model XRD-6100, using $\mathrm{Cu}$ k $\alpha 1$ emission. The source potential was $40 \mathrm{kV}$ and the current $30 \mathrm{~mA}$. A sweep rate with a step of $0.02^{\circ}$ every second was applied. The sweep range 
(20) was from 5 to $70^{\circ}$. The identification of the peaks was performed with the aid of the program 'Raio $\mathrm{X}$ v. 1.0.0.37', and the minerals were identified according to Chen (1977).

The obtained data were analyzed by Pearson linear correlation between the physical and chemical attributes of the evaluated profiles. In addition, multivariate analysis was used as a tool for soil profile distinction, and the Principal Component Analysis (PCA) procedure was applied using STATISTICA 7.0 software.

\section{Results}

Two soil classes were identified in the Tabuleiro Grande Settlement Project. When classified into 4th categorical level, the profiles P1 and P3 are Vertissolo Háplico Órtico chernossólico (VXo), and the profile P2 is Chernossolo Rêndzico Petrocálcico típico (MDlk).

When analyzing the morphological descriptions, a strong structure degree is observed in all profiles except P2 (MDlk), which has a moderate structure degree (Table 2). The structure of P2 is of granular type along the profile with sizes ranging from small to very small. The profiles P1 (VXo) and P3 (VXo) presented similarities in the structure type, with granular structure in the superficial horizon contrasting with blocks and prisms in the subsurface horizons. This type of feature, typical of the Vertisols, is called self-granulation, caused due to the presence of cracks in the profile. The cracks were observed in the subsurface horizons of profile P1 (VXo), measuring up to $3.0 \mathrm{~cm}$ wide, and in the horizons A and Bv1 of profile P2 (MDlk), with $2.0 \mathrm{~cm}$ width. Similar results were obtained by Lima (2014), regarding the degree and type of structure in the surface and subsurface horizons in Haplic Vertisols inserted in calcareous regions in the municipalities of Juazeiro and Terra Nova in the state of Bahia.Profiles P1 (VXo) and P3 (VXo) showed abundant friction surfaces (slickensides) on horizons Bv1 and Bv2 (P1) and horizon Bv2 (P3), demonstrating the strong expandability of the clay material of these profiles.

Table 2. Morphologic attributes of soil profiles of Apodi Plateau, RN, Brazil

\begin{tabular}{|c|c|c|c|c|c|c|c|c|}
\hline \multirow{2}{*}{$\begin{array}{l}\text { Horizon/ } \\
\text { Depth }(\mathrm{cm})\end{array}$} & \multirow{2}{*}{ Elevation $(\mathrm{m})$} & \multirow{2}{*}{ Color } & \multirow{2}{*}{ Parent Material } & \multirow{2}{*}{ Structure } & \multicolumn{3}{|c|}{ Consistency } & \multirow{2}{*}{ Boundary } \\
\hline & & & & & Dry & Wet & Moist & \\
\hline \multicolumn{9}{|c|}{ Profile 1: VERTISSOLO HÁPLICO Órtico chernossólico (VXo) (Chernosols) } \\
\hline $\mathrm{A}(0-34)$ & \multirow{4}{*}{101} & $10 \mathrm{YR} 3 / 2$, dry & \multirow{4}{*}{$\begin{array}{l}\text { LIMESTONE } \\
\text { (Cretaceous, Apodi Group) }\end{array}$} & 3 Vf Bls FM Gr & VHA & $\mathrm{F}$ & SLPL SL ST & $\mathrm{SC}$ \\
\hline Bv1 (34-85) & & $2,5 \mathrm{Y} 3 / 2$, dry & & $3 \mathrm{VfPr}$ & VHA & $\mathrm{F}$ & SLPL SL ST & SG \\
\hline Bv2 (85-131) & & $2,5 \mathrm{Y} 3 / 2$, dry & & 3 C Bla & VHA & VFI & PL ST & $\mathrm{SC}$ \\
\hline $\mathrm{Cr}(131-148+)$ & & $\begin{array}{l}2,5 Y 4 / 4, \text { dry } \\
\text { (lime. Frag.) }\end{array}$ & & - & - & - & - & - \\
\hline \multicolumn{9}{|c|}{ Profile 2: CHERNOSSOLO RÊNDZICO Petrocálcico tipico (MDlk) (Chernosols) } \\
\hline Ak $(0-39)$ & \multirow{2}{*}{107} & $10 \mathrm{YR} 4 / 3$, dry & \multirow{2}{*}{$\begin{array}{l}\text { LIMESTONE } \\
\text { (Cretaceous, Apodi Group) }\end{array}$} & $2 \mathrm{Vf} \mathrm{Gr} \mathrm{F} \mathrm{Gr}$ & $\mathrm{S}$ & VFR & PL ST & SA \\
\hline Crk (39-63) & & 10 YR $7 / 4$, dry & & 2Mp Gr P Gr & $\mathrm{S}$ & VFR & PL ST & - \\
\hline \multicolumn{9}{|c|}{ Profile 3: VERTISSOLO HÁPLICO Órtico chernossólico (VXo) (Vertisols) } \\
\hline$A(0-34)$ & \multirow{5}{*}{107} & \multicolumn{2}{|c|}{ 10YR 3/1, dry } & 3 FM Gr & $\mathrm{Ha}$ & FR & SL PL ST & SD \\
\hline Bv1 (34-104) & & \multicolumn{2}{|l|}{$10 \mathrm{YR} 4 / 2$, dry } & $3 \mathrm{CPr}$ & VHA & FI & PL ST & SD \\
\hline Bv2 (104-145) & & $2,5 \mathrm{Y} 4 / 1$, dry & \multirow{3}{*}{$\begin{array}{l}\text { LIMESTONE } \\
\text { (Cretaceous, Apodi Group) }\end{array}$} & $3 \mathrm{CPr}$ & VHA & EFI & PL ST & SA \\
\hline \multirow[t]{2}{*}{$\mathrm{Cr}(145-160)$} & & $2,5 Y$ 7/6 dry & & & & & & \\
\hline & & $\begin{array}{l}2,5 \text { Y } 8 / 2 \\
\text { (lime. frag.) }\end{array}$ & & - & - & - & - & - \\
\hline
\end{tabular}

Note. lime. frag.: limestone fragments. Structure: 1-weak; 2-moderate; 3-strong; Vf: very fine; F: fine; M: medium; C: coarse; VC: very coarse; Gr: granular; Bla: angular blocky; Bls: subangular blocky; Pr: prismatic. Consistence: SO: soft; EHA: extremely hard; Ha: hard; VHA: very hard; VFI: very firm; FI: firm; EFI: extremely firm; FR: friable; VFR: very friable; N: Non, V: very: SL: slightly; PL: plastic; ST: sticky. Boundary: S: smooth; D: diffuse; G: gradual; A: abrupt; C: clear.

The color of the profiles varied between dark brown on the surface horizons and yellowish brown on the subsurface horizons (Table 2). In the Cr horizons of the P2 (MDlk) and P3 (VXo) profiles, light gray (P2) and yellow (P3) coloration were observed. The dark color in the Vertisols is due to the presence of organic constituents, mainly in the superficial horizons (Dudal \& Eswaran, 1988). In addition to these constituents, the 2:1 clay mineral smectite also influences the dark coloration of these soils. 
Soil consistency (Table 2) in P1 (VXo) and P3 (VXo) profiles is predominantly very hard, when dry, and varies from friable, firm to extremely firm, when wet. The fact that the consistency is plastic and sticky when wet can be explained by the presence of expansive 2:1 clays, typic of Vertisols. P2 (MDlk) has a soft consistency when dry, very friable when wet, and slightly plastic and sticky when wet. Similar results were obtained by Melo et al. (2017) in relation to the surface and subsurface horizon consistency of a Rendzic Chernosol in the state of Rio Grande do Norte, derived from material of limestone origin.

Clay and silt contents (Table 3) in Vertisols ranged from 76 to $273 \mathrm{~g} \mathrm{~kg}^{-1}$ and 114 to $677 \mathrm{~g} \mathrm{~kg}^{-1}$, respectively. Sand contents ranged from 226 to $665 \mathrm{~g} \mathrm{~kg}^{-1}$ and, in general, the fine sand fraction predominated over coarse sand, which is a positive aspect for moisture retention. The clay content was considered low for Vertisols (P1 and P3), which may be due to the climate of the region, which caused less intense weathering and provided larger amounts of sand. However, clay contents ranging from 547 to $710 \mathrm{~g} \mathrm{~kg}^{-1}$ were observed in Haplic Vertisols of the island of Fernando de Noronha, located in areas of quaternary deposits composed of calcareous, psammitic and pellitic sediments (Marques et al., 2014).

Table 3. Physical attributes of soil profiles of Apodi Plateau, RN, Brazil.

\begin{tabular}{|c|c|c|c|c|c|c|}
\hline Horizon/Depth $(\mathrm{cm})$ & Coarse sand & Fine sand & Silt & Clay & Silt/Clay & Textural Class \\
\hline \multicolumn{7}{|c|}{ 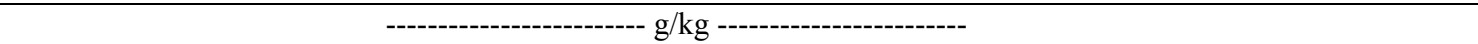 } \\
\hline \multicolumn{7}{|c|}{ Profile 1: VERTISSOLO HÁPLICO Órtico chernossólico (VXo) (Chernosols) } \\
\hline $\mathrm{A}(0-34)$ & 142 & 523 & 114 & 220 & 0.52 & SANDY-CLAY-LOAM \\
\hline Bv1 (34-85) & 32 & 567 & 195 & 207 & 0.94 & SANDY-CLAY-LOAM \\
\hline Bv2 (85-131) & 24 & 567 & 219 & 190 & 1.16 & SANDY-LOAM \\
\hline $\mathrm{Cr}(131-148+)^{*}$ & - & - & - & - & - & - \\
\hline \multicolumn{7}{|c|}{ Profile 2: CHERNOSSOLO RENDZICO Petrocálcico tipico (MDlk) (Chernosols) } \\
\hline Ak (0-39) & 51 & 196 & 677 & 76 & 8.85 & SILTY-LOAM \\
\hline Crk (39-63) & 48 & 178 & 477 & 298 & 1.60 & CLAY-LOAM \\
\hline \multicolumn{7}{|c|}{ Profile 3: VERTISSOLO HÁPLICO Órtico chernossólico (VXo) (Vertisols) } \\
\hline $\mathrm{A}(0-34)$ & 192 & 390 & 222 & 197 & 1.12 & SANDY-LOAM \\
\hline Bv1 (34-104) & 26 & 306 & 395 & 273 & 1.44 & CLAY-LOAM \\
\hline Bv2 (104-145) & 21 & 469 & 297 & 212 & 1.39 & LOAM \\
\hline $\mathrm{Cr}(145-160)^{*}$ & - & - & - & - & - & - \\
\hline
\end{tabular}

Note. * Limestone Fragments.

Different soil textural classes were observed in soil profiles and horizons (Table 3). The sandy-clay-loam texture predominated in surface horizons of profiles P1 (VXo) and P3 (VXo). It was also observed the sandy-loam texture in the subsurface horizon of P1, in addition to the clay-loam and loam in subsurface horizons in P3. In the P2 profile (MDlk), the silt-loam texture was observed in the superficial horizon and the clay-loam in the Crk horizon. In this profile, the silt fraction predominated, which indicates little weathering activity. The silty-loam texture and high silt contents were observed in the surface horizon of a Rendzic Chernosol by Melo et al. (2017). The silt/clay ratio, which indicate the degree of soil development, ranged from 0.52 to 1.44 in the P1 (VXo) and P3 (VXo) profiles, with higher values in subsurface horizons. In the P2 profile (MDlk), this ratio was higher in surface and decreased with depth.

Regarding chemical attributes (Table 4), the three profiles (P1, P2 and P3) presented values close to $\mathrm{pH}$ in water, ranging from 7.77 to 8.27 in surface and subsurface horizons. These values identify the parent material of these soils, limestone, and characterize more alkaline soils. The low EC values in the studied profiles, between 0.11 and $0.26 \mathrm{dS} \mathrm{m}^{-1}$ (Table 4), indicate that the salt levels in the soil solution are not high.

The TOC values ranged from 22.5 to $26.2 \mathrm{~g} \mathrm{~kg}^{-1}$ in all horizons of the three soil profiles (Table 4). Similar values were obtained by Marques et al. (2014) on surface horizons of Haplic Vertisols on the island of Fernando de Noronha, PE, Brazil. The low organic carbon content obtained by us is due to the region's semiarid climate and hyperxerophilous Caatinga vegetation, which provides little primary biomass. In addition, low rainfall slows down the process of plant decomposition. 
Table 4. Chemical attributes of soil profiles at the Apodi Plateau, RN, Brazil

\begin{tabular}{|c|c|c|c|c|c|c|c|c|c|c|c|c|c|c|}
\hline Horizon & $\mathrm{pH}-\mathrm{H}_{2} \mathrm{O}$ & EC & TOC & $\mathrm{K}^{+}$ & $\mathrm{Ca}^{2+}$ & $\mathrm{Mg}^{2+}$ & $\mathrm{Na}^{+}$ & $\mathrm{Al}^{3+}$ & PA & $\mathrm{T}$ & $\mathrm{P}$ & $\mathrm{V}$ & $\mathrm{m}$ & ESP \\
\hline & & $\mathrm{dS} \mathrm{m}^{-1}$ & $\mathrm{gkg}^{-1}$ & \multicolumn{7}{|c|}{ - } & $m g \mathrm{~kg}^{-1}$ & \multicolumn{3}{|c|}{------- \% ------- } \\
\hline \multicolumn{15}{|c|}{ Profile 1: VERTISSOLO HÁPLICO Órtico chernossólico (VXo) } \\
\hline A & 8.00 & 0.11 & 22.5 & 0.37 & 50.50 & 19.33 & 0.10 & 0.00 & 0.43 & 70.73 & 2.36 & 99 & 0 & 0 \\
\hline Bv1 & 8.06 & 0.15 & 23.9 & 0.11 & 39.50 & 31.50 & 0.20 & 0.00 & 0.48 & 71.79 & 1.82 & 99 & 0 & 0 \\
\hline Bv2 & 8.19 & 0.15 & 22.5 & 0.14 & 31.20 & 37.20 & 0.44 & 0.00 & 0.58 & 69.56 & 2.16 & 99 & 0 & 0 \\
\hline $\mathrm{Cr}^{*}$ & - & - & - & - & - & - & - & - & - & - & - & - & - & - \\
\hline \multicolumn{15}{|c|}{ Profile 2: CHERNOSSOLO RENDZICO Petrocálcico tipico (MDlk) } \\
\hline Ak & 8.01 & 0.21 & 25.6 & 0.13 & 44.83 & 10.67 & 2.34 & 0.00 & 0.78 & 58.75 & 1.29 & 99 & 0 & 4 \\
\hline Crk & 8.12 & 0.13 & 23.8 & 0.03 & 32.83 & 8.50 & 2.34 & 0.00 & 0.63 & 44.33 & 0.83 & 99 & 0 & 5 \\
\hline \multicolumn{15}{|c|}{ Profile 3: VERTISSOLO HÁPLICO Órtico chernossólico (VXo) } \\
\hline A & 7.77 & 0.26 & 26.2 & 0.82 & 49.33 & 21.17 & 0.10 & 0.00 & 1.23 & 72.65 & 3.19 & 98 & 0 & 0 \\
\hline Bv1 & 8.27 & 0.14 & 24.6 & 0.11 & 41.00 & 28.83 & 0.97 & 0.00 & 0.63 & 71.54 & 2.51 & 99 & 0 & 1 \\
\hline Bv2 & 8.10 & 0.21 & 22.7 & 0.10 & 30.33 & 35.50 & 2.97 & 0.00 & 0.53 & 69.43 & 1.31 & 99 & 0 & 4 \\
\hline $\mathrm{Cr} *$ & - & - & - & - & - & - & - & - & - & - & - & - & - & - \\
\hline
\end{tabular}

Note. EC: Electrical Conductivity; TOC: Total Organic Carbon; PA: Potential Acidity; T: Cation Exchange Capacity; V: Base Saturation; ESP: Exchangeable Sodium percentage; * Sandstone Fragments.

The high $\mathrm{Ca}^{2+}$ contents in all horizons, ranging from 30.33 to $50.50 \mathrm{cmolc} \mathrm{kg}{ }^{-1}$ (Table 4), are due to the fact that calcium is the main component of limestone. $\mathrm{Mg}^{2+}$ levels were also high, except for P2 (MDlk), and ranged from 19.33 to $37.20 \mathrm{cmolc} \mathrm{kg}^{-1}$. High $\mathrm{Mg}^{2+}$ and $\mathrm{Ca}^{2+}$ contents reflect the nature of the parent material. High levels of these cations were observed by Corrêa et al. (2003) in Vertisols originated from calciferous clay and sandstone in the Lowlands of Sousa, PB, Brazil. Meanwhile, the low $\mathrm{Na}^{+}$and $\mathrm{K}^{+}$contents in all horizons of the three soil profiles reflect the low amount of these elements in the parent material.

T values ranged from 69.56 to $71.79 \mathrm{cmolc} \mathrm{kg}^{-1}$ at $\mathrm{P} 1$ (VXo); 44.33 to $58.75 \mathrm{cmolc} \mathrm{kg}^{-1}$ at $\mathrm{P} 2$ (MDlk); and from 69.43 to $72.65 \mathrm{cmolc} \mathrm{kg}^{-1}$ in P3 (VXo) (Table 4). These high values were related to the nature and texture of soil clay minerals. The soils studied were eutrophic, with V values ranging from 98.31 to $99.39 \%$ (Table 4). The ESP ranged from 0.14 to $4.28 \%$ (Table 4) in profiles P1 and P3. Among the profiles, P2 presented the highest sodium content and highest ESP, which may indicate a higher propensity for dispersion.

The P content in profile 2 (MDlk) ranged from 0.83 to $1.29 \mathrm{mg} \mathrm{kg}^{-1}$ (Table 4), which is considered low compared to typical soils of this class, which generally have high fertility and between 3 and $20 \mathrm{mg} \mathrm{kg}^{-1}$ of P. The P1 (VXo) and P3 (VXo) profiles also presented low P values (1.31 to $3.19 \mathrm{mg} \mathrm{kg}^{-1}$ ), determined by the ion exchange resin method. In this sense, Silveira, Bezerra, De Sá, and Valadares (2006) report low P extraction by the resin method in different soils of the semiarid region of Paraíba and Pernambuco states, including Vertisols.

Significant linear correlations were observed between the physical and chemical attributes of the studied soil profiles (Table 5). Among them is the positive relationship between Coarse Sand (CS) and $\mathrm{K}^{+}(0.93)$. This indicates that the weathering process is not very pronounced in the studied area, since the high $\mathrm{K}^{+}$contents are directly related to areas with a sandy texture, which determines the gradual release of this nutrient to the soil system. The same behavior was observed for $\mathrm{Ca}^{2+}$, whose correlation with CS is 0.79 . The significant correlation between $\mathrm{Mg}^{2+}$ and Fine Sand (FS) can be interpreted in the same way as that of $\mathrm{K}^{+}$and $\mathrm{Ca}^{2+}$ with sand. The three elements mentioned are those basically made available to the soil system by the process of hydrolysis and breakage of primary minerals present in the parent material exposed to the pedogenetic process. The other correlations between the attributes confirmed the expected behavior for these soils. 
Table 5. Pearson linear correlation $(\mathrm{p}<0.05)$ between physical and chemical attributes of soil profiles Apodi Plateau, RN, Brazil

\begin{tabular}{|c|c|c|c|c|c|c|c|c|c|c|c|c|c|c|c|c|c|}
\hline & pH & $\mathrm{C}$ & $\mathrm{OC}$ & $\mathbf{K}$ & $\mathrm{Ca}$ & Mg & $\mathbf{N a}$ & $\mathbf{I + A I}$ & CEC & $\mathbf{P}$ & BS & ESP & $\mathrm{CS}$ & FS & Silt & Clay & Silt/Clay \\
\hline pH & .00 & .64 & .51 & .84 & -0.64 & 0.35 & 26 & .68 & 14 & -0.37 & 0.54 & 0.24 & -0.85 & -0.02 & 18 & .38 & 10 \\
\hline EC & -0.64 & 1.00 & 0.64 & 0.55 & 0.16 & 0.00 & 0.19 & 0.80 & 0.19 & 0.22 & -0.60 & 0.08 & 0.34 & 0.15 & 20 & 0.51 & 34 \\
\hline TOC & -0.51 & 0.64 & 1.00 & 0.47 & 0.51 & -0.46 & -0.03 & 0.83 & -0.07 & 0.28 & -0.78 & 0.00 & 0.38 & -0.58 & 0.48 & -0.32 & 0.49 \\
\hline $\mathbf{K}$ & -0.84 & 0.55 & 0.47 & 1.00 & 0.69 & -0.10 & -0.54 & 0.75 & 0.42 & 0.78 & -0.46 & -0.54 & 0.93 & 0.15 & -0.41 & -0.14 & -0.20 \\
\hline $\mathrm{Ca}$ & -0.64 & 0.16 & 0.51 & 0.69 & 1.00 & -0.42 & -0.53 & 0.40 & 0.31 & 0.60 & -0.22 & -0.51 & 0.79 & -0.06 & -0.12 & -0.29 & 0.17 \\
\hline Mg & 0.35 & 0.00 & -0.46 & -0.10 & -0.42 & 1.00 & -0.25 & -0.30 & 0.73 & 0.30 & 0.63 & -0.44 & -0.36 & 0.78 & -0.58 & 0.09 & -0.50 \\
\hline $\mathrm{Na}$ & 0.26 & 0.19 & -0.03 & -0.54 & -0.53 & -0.25 & 1.00 & -0.12 & -0.60 & -0.80 & -0.18 & 0.96 & -0.50 & -0.58 & 0.70 & -0.08 & 0.47 \\
\hline $\mathbf{H}+\mathbf{A l}$ & -0.68 & 0.80 & 0.83 & 0.75 & 0.40 & -0.30 & -0.12 & 1.00 & 0.03 & 0.47 & -0.87 & -0.09 & 0.61 & -0.36 & 0.19 & -0.24 & 0.21 \\
\hline CEC & -0.14 & 0.19 & -0.07 & 0.42 & 0.31 & 0.73 & -0.60 & 0.03 & 1.00 & 0.75 & 0.46 & -0.80 & 0.22 & 0.74 & -0.66 & -0.16 & -0.36 \\
\hline $\mathbf{P}$ & -0.37 & 0.22 & 0.28 & 0.78 & 0.60 & 0.30 & -0.80 & 0.47 & 0.75 & 1.00 & -0.05 & -0.86 & 0.63 & 0.39 & -0.57 & 0.02 & -0.39 \\
\hline BS & 0.54 & -0.60 & -0.78 & -0.46 & -0.22 & 0.63 & -0.18 & -0.87 & 0.46 & -0.05 & 1.00 & -0.30 & -0.44 & 0.69 & -0.49 & 0.13 & -0.36 \\
\hline ESP & 0.24 & 0.08 & 0.00 & -0.54 & -0.51 & -0.44 & 0.96 & -0.09 & -0.80 & -0.86 & -0.30 & 1.00 & -0.44 & -0.69 & 0.74 & 0.03 & 0.45 \\
\hline CS & -0.85 & 0.34 & 0.38 & 0.93 & 0.79 & -0.36 & -0.50 & 0.61 & 0.22 & 0.63 & -0.44 & -0.44 & 1.00 & 0.04 & -0.36 & -0.07 & -0.16 \\
\hline FS & -0.02 & -0.15 & -0.58 & 0.15 & -0.06 & 0.78 & -0.58 & -0.36 & 0.74 & 0.39 & 0.69 & -0.69 & 0.04 & 1.00 & -0.88 & -0.01 & -0.59 \\
\hline Silt & 0.18 & 0.20 & 0.48 & -0.41 & -0.12 & -0.58 & 0.70 & 0.19 & -0.66 & -0.57 & -0.49 & 0.74 & -0.36 & -0.88 & 1.00 & -0.33 & 0.84 \\
\hline Clay & 0.38 & -0.51 & -0.32 & -0.14 & -0.29 & 0.09 & -0.08 & -0.24 & -0.16 & 0.02 & 0.13 & 0.03 & -0.07 & -0.01 & -0.33 & 1.00 & -0.77 \\
\hline Silt/Clay & -0.10 & 0.34 & 0.49 & -0.20 & 0.17 & -0.50 & 0.47 & 0.21 & -0.36 & -0.39 & -0.36 & 0.45 & -0.16 & -0.59 & 0.84 & -0.77 & 1.00 \\
\hline
\end{tabular}

Note. EC: Electrical Conductivity; TOC: Total Organic Carbon; CEC: cation exchange capacity; BS: base saturation; ESP: Exchangeable Sodium Percentage; CS: CoarseSand; FS: Fine Sand. CEC: Cation Exchange Capacity; BS: Base Saturation.

The ordering diagram resulting from the PCA (Figure 1) presents distinct groups between the horizons of the evaluated soil profiles. According to SiBCS (Santos et al., 2018) there are two soil classes diagnosed in the studied area, and the distinction between them is confirmed by the PCA. In this respect, the horizons of Vertisol (P1 and P3) form a single group in the ordering diagram, except for horizon A of profile P3, which differs from the others. The other group formed includes the horizons of the P2 profile, which is classified as Chernosol. This grouping confirms that the physical and chemical attributes of these two soil classes are distinct, with a cumulative total variance of $72.36 \%$ (Table 6 ). 


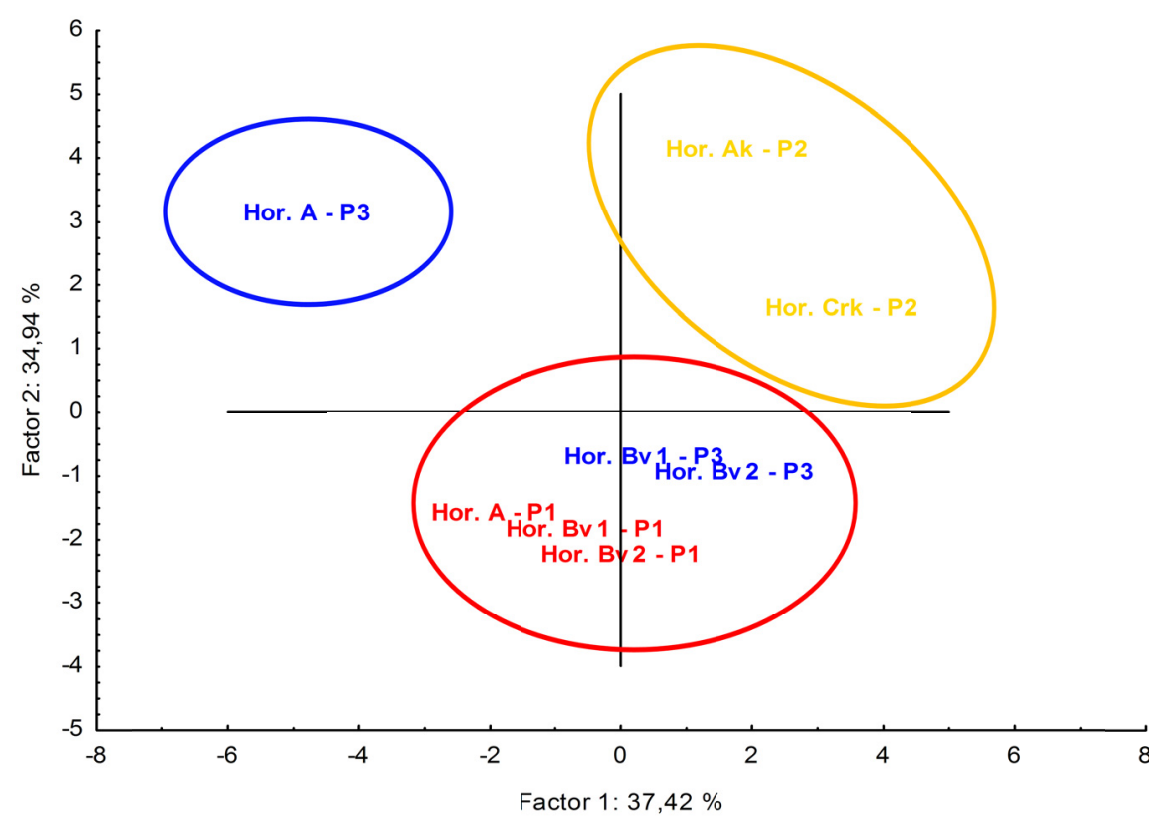

Figure 1. Ordination diagram of Factors 1 and 2 of physical and chemical attributes of soil profiles evaluated in Apodi Plateau, RN, Brazil

Note. Group 1: blue circle, Group 2: yellow circle, and Group 3: red circle.

Table 6. Correlation coefficients of principal components (Factors 1 and 2) for physical and chemical attributes of soil profiles of Apodi Plateau, RN, Brazil

\begin{tabular}{|c|c|c|}
\hline Atributtes & Factor 1 & Factor 2 \\
\hline $\mathrm{pH}$ & 0.67 & -0.55 \\
\hline $\mathrm{CE}$ & -0.34 & 0.62 \\
\hline СOT & -0.30 & 0.83 \\
\hline K & -0.91 & 0.34 \\
\hline $\mathrm{Ca}$ & -0.69 & 0.37 \\
\hline $\mathrm{Mg}$ & -0.18 & -0.75 \\
\hline $\mathrm{Na}$ & 0.80 & 0.34 \\
\hline $\mathrm{H}+\mathrm{Al}$ & -0.52 & 0.75 \\
\hline $\mathrm{T}$ & -0.70 & -0.47 \\
\hline$P$ & -0.92 & -0.10 \\
\hline V & 0.12 & -0.89 \\
\hline PST & 0.84 & 0.42 \\
\hline AG & -0.81 & 0.37 \\
\hline $\mathrm{AF}$ & -0.47 & -0.78 \\
\hline Silt & 0.64 & 0.69 \\
\hline Arg & 0.11 & -0.41 \\
\hline Silt/Arg & 0.36 & 0.68 \\
\hline Total Variance (\%) & 37.42 & 34.94 \\
\hline Accumulated Variance (\%) & 37.42 & 72.36 \\
\hline
\end{tabular}

The diagram of vector projection (Figure 2) and the PCA correlation coefficients (Table 5) indicate that the physical and chemical attributes that most influenced the formation of the PCA groups are different for each group. In Group 1 (blue color), the attributes that most influenced the distinction of horizon A of the P3 profile were: TOC, $\mathrm{H}+\mathrm{Al}, \mathrm{CS}$, and $\mathrm{K}^{+}$. When this result is compared with the analytical data obtained, it is observed that in this horizon the TOC was higher than that of other horizons, as well as $\mathrm{H}+\mathrm{Al}, \mathrm{K}^{+}$, and CS (Table 4). In Group 2 (yellow color) the most influential attributes for the separation from the other groups were $\mathrm{Na}+$ and 
ESP, being P2 the only one that presented higher levels of sodium throughout the profile and consequent higher risk of sodicity. The formation of Group 3 (red color) was more influenced by the attributes P, T, FS, $\mathrm{Mg}^{2+}$ and V. This shows that the chemical attributes were more important for distinguishing this group from the others. It can also be observed in the $\mathrm{P} 2$ and $\mathrm{P} 3$ profiles the highest $\mathrm{P}$, and $\mathrm{Mg}^{2+}$ content, higher $\mathrm{T}$ value, and $\mathrm{V}$ values close to $100 \%$, which determine eutrophic character. The FS also stands out in the distinction for presenting higher values in $\mathrm{P} 1$ and $\mathrm{P} 3$ when compared to $\mathrm{P} 2$.

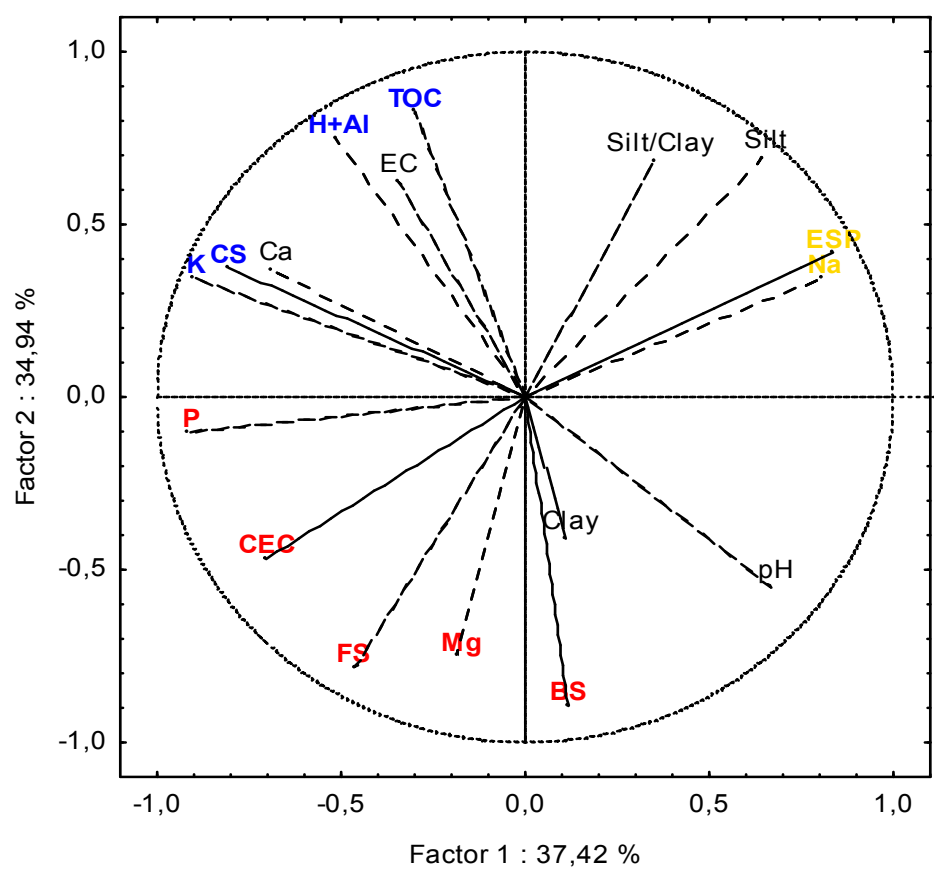

Figure 2. Projection diagram of vector of physical and chemical attributes of soil profiles in Apodi Plateau, RN, Brazil

These findings help in the interpretation of the landscape, as it is possible to separate the most influential physical and chemical attributes in each soil class studied. This is fundamental for evaluations of practical implications in Vertisols and Chernosols in the Apodi Plateau region, as these attributes become indicators of these soils, making possible a faster and more accurate diagnosis of the attributes that may be limiting for agricultural production or that can potentiate such activity.

X-ray diffractometry (XRD) (Figure 3) showed that the mineralogical composition in the ADFE of the diagnostic horizons of the soils studied is mainly quartz, followed by the illite mineral. There is also the occurrence of calcite and montmorillonite. In studies of J. C. A. Mota, Assis Júnior, Amaro Filho, Ilho, Romero, F. O. B. Mota, and Libardi (2007), in the Apodi Plateau, quartz minerals predominate over other constituents, which is due to its being extremely resistant to weathering.

The illite, a 2:1 clay mineral originated from the mica transformation, was identified in all evaluated horizons of the three profiles. This is due to the calcareous parent material in which micaceous minerals are common (Kampf \& Curi, 2003). The presence of illite was also observed in a study by Oliveira et al. (1998) in soils developed from limestone of the Bambuí Group (MG, Brazil), in addition to small amounts of other expansive clay minerals.

The horizons Ak and Bv2 of profiles P2 and P3, respectively, presented in common the calcite (Figures 3A and 3B). The occurrence of this mineral is due to the nature of the parent material, limestone, which is formed from the calcite mineral. Calcite was also found by Lemos, Curi, Marques, and Sobrinho (1997) on the fine sand fraction of soil profiles of the Apodi Plateau.

In addition to the minerals already mentioned, montmorillonite (Figure 3C), a partially expansive 2:1 mineral, was found on horizon Bv2 of profile P3. This indicates a soil with less weathered minerals due to the climate of the region. This same clay mineral was identified by Lima et al. (2015) in the clay fraction of a Vertisol originated from clay shales and limestones in the Santo Amaro region, BA, Brazil. The formation of more 
resistant clay minerals, type 2:1, common in the three studied profiles, is attributed to the chemical constitution of the parent material, the scarce precipitation, and the flat topography of the area, which make it difficult to leave the base and silica out of the system.
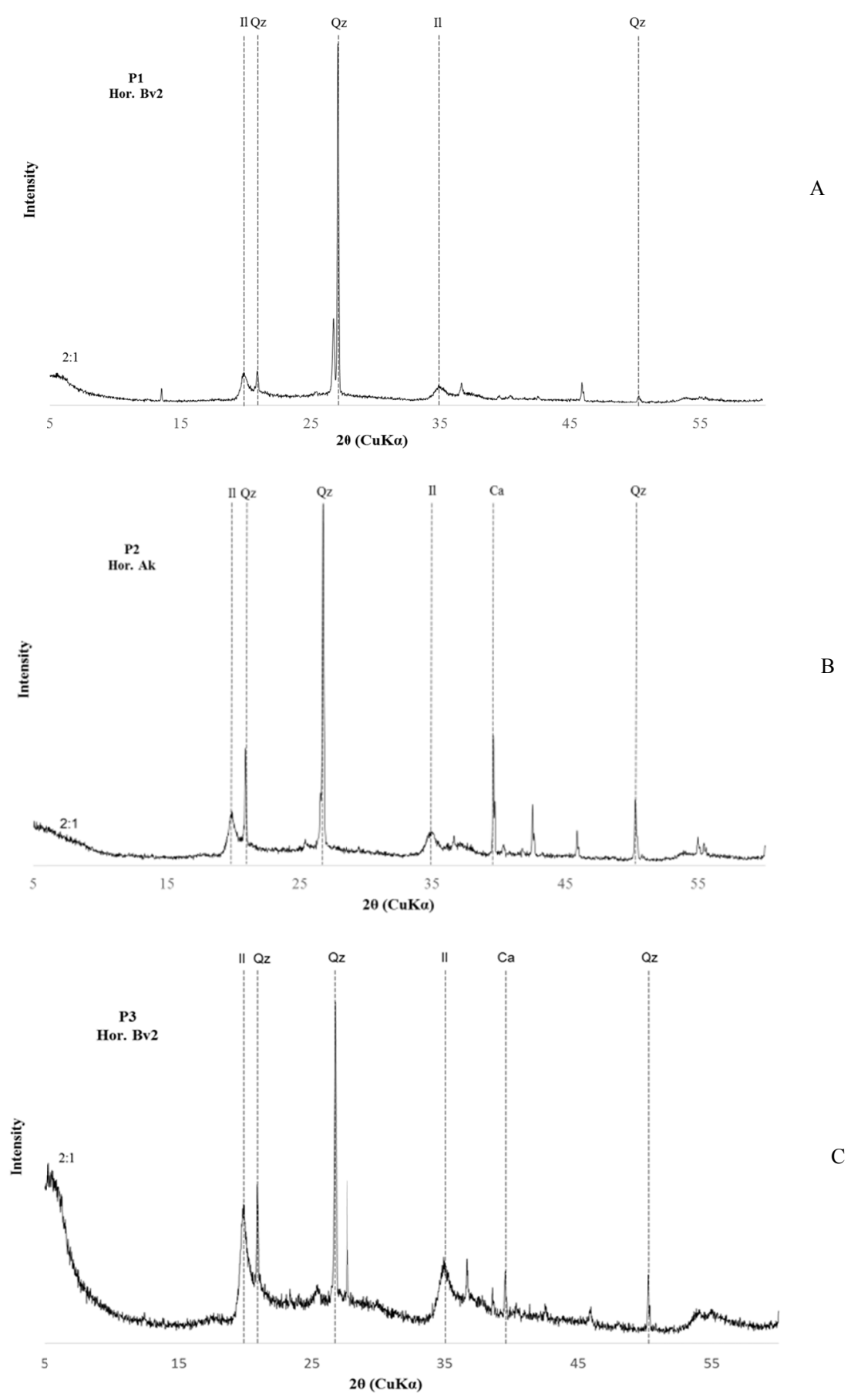

Figure 3. A) X ray difratometry in the ADSS of diagnostic horizons from profiles of Bv2 do Vertissolo Háplico Órtico chernossólico (P1); B) X ray difratometry in the ADSS of diagnostic horizons from profiles of Ak do Chernossolo Rêndzico Petrocálcico típico (P2); C) X ray difratometry in the ADSS of diagnostic horizons from profiles of Bv2 do Vertissolo Háplico Órtico chernossólico (P3). Il: Ilite; Qz: Quartzo; 2:1: clay mineral type 2:1;

Ca: kaolinite; Mt: Montmorillonite 


\section{Acknowledgments}

Three soil classes were identified up to the 4th categorical level in the Tabuleiro Grande Settlement Project: VERTISSOLO HÁPLICO Órtico chernossólico, CHERNOSSOLO RÊNDZICO Petrocálcico típico, and VERTISSOLO HÁPLICO Órtico chernossólico.

The predominant textures in the surface horizons of profiles P1 and P2 were Sandy-Clay-Loam, in addition to Sandy-Loam in the subsurface horizon of P1, and Clay-Loam and loam in subsurface horizons of P3.

Predominance of quartz and illite was observed in the profiles of soils of limestone origin. In addition, the profiles $\mathrm{P} 2$ and $\mathrm{P} 3$ presented peaks of montmorillonite and calcite in the ADFE.

\section{References}

Alvarez, C. A., Stape, J. L., Sentelhas, P. C., Gonçalves, J. L. M., \& Sparovek, G. (2013). Köppen's climate classification map for Brazil. Meteorologische Zeitschrift, 22(6), 711-728. https://doi.org/10.1127/09412948/2013/0507

Chen, P. Y. (1977). Table of key lines in X-ray powder diffraction patterns of minerals in clays and associated rocks: Geological Survey Occasional Paper 21. Bloomington, Indiana Geological Survey Report (p. 67).

Corrêa, M. M., Ker, J. C., Mendonça, E. S., Ruiz, H. A., \& Bastos, R. S. (2003). Atributos físicos, químicos e mineralógicos de solos da região das Várzeas de Sousa (PB). Revista Ministério do Meio Ambiente eira de Ciência do Solo, 27(2), 311-324. https://doi.org/10.1590/S0100-06832003000200011

Dudal, R., \& Eswaran, E. (1988). Distribution, properties and classification of Vertisols. In L. P. Wilding, \& R. Puentes (Eds.), Vertisols: Their distribution, properties, classification and management (pp. 1-22). Texas A\&M University Printing Centre, College Station, Texas. Elsevier, Amsterdam.

Ernesto Sobrinho, F. (1979). Caracterização, gênese e interpretação para uso de solos derivados de calcário da região da Chapada do Apodi, Rio Grande do Norte (133f., Dissertação, Mestrado em Solos e Nutrição de Plantas, Universidade Federal de Viçosa, MG).

Kampf, N., \& Curi, N. (2003). Argilominerais em solos brasileiros. In N. Curi, J. J. Marques, L. R. G. Guilherme, J. M. Lima, A. S. Lopes, \& V. H. Alvarez (Eds.), Tópicos em ciência do solo (V. 3, pp. 1-54). Viçosa, MG, Sociedade Brasileira de Ciência do Solo.

Lemos, M. S. S., Curi, N., Marques, J. J. G. de S. M., \& Sobrinho, F. E. (1997). Evaluation of characteristics of Cambisols derived from limestone in low tablelands in northeastern Brazil: Implications for management. Pesquisa Agropecuária Brasileira, 32, 825-834.

Lima, G. K. (2014). Caracterização de Vertissolos do nordeste brasileiro (101f., Tese de Doutorado Dissertação, Mestrado em Ciência do Solo, Universidade Federal Rural de Pernambuco, Recife).

Lima, L. R. P. A., Souza, R. C., \& Bernardez, L. A. (2015). Caracterização da fração argilosa do solo superficial na região da fundição de chumbo em santo amaro, Bahia. Holos, 31(2), 15. https://doi.org/10.15628/ holos.2015.1829

Marques, F. A., Souza, R. A. S., Souza, J. E. S., Lima, J. F. W. F., \& Souza Júnior, V. S. (2014). Characterization of vertisols from the island of Fernando de Noronha, Pernambuco, Brazil. Revista Brasileira de Ciência do Solo, 38(4), 1051-1065. https://doi.org/10.1590/S0100-06832014000400002

Melo, A. F. D., Souza, C. M. M., Rêgo, L. G. S., Lima, R. N. S., Moura, I. N. B. M. (2017). Pedogênese de chernossolos derivados de diferentes materiais de origem no oeste potiguar. Agropecuária Científica no Semiárido, 13(3), 229-235. https://doi.org/10.30969/acsa.v13i3.890

MMA (Ministério do Meio Ambiente). (2019). Caatinga. Retrieved April 23, 2019, from http://www.mma.gov. $\mathrm{br} / \mathrm{biomas} /$ caatinga

Mota, J. C. A., Assis Júnior, R. N., Amaro Filho, J., Romero, R. E., Mota, F. O. B., \& Libardi, P. L. (2007). Atributos mineralógicos de três solos explorados com a cultura do melão na Chapada do Apodi-RN. Revista Brasileira de Ciência do Solo, 31(3), 445-454. https://doi.org/10.1590/S0100-06832007000300004

Oliveira, C. V., Ker, J. C., Fontes, L. E. F., Curi, N., \& Pinheiro, J. C. (1998). Química e mineralogia de solos derivados de rochas do Grupo Bambuí no norte de Minas Gerais. Revista Brasileira de Ciência do Solo, 22, 583-593. https://doi.org/10.1590/S0100-06831998000400003

Pessoa Neto, O. C., Soares, U. M., Silva, J. G. F., Roesner, E. H., Florencio, C. P., \& Souza, C. A. V. (2007). Litoestratigrafia da Bacia Potiguar. Boletim de Geociências da Petrobrás, 15(2), 357-369. 
Santos, H. G. dos, Jacomine, P. K. T., Anjos, L. H. C. dos, Oliveira, V. A. de, Lumbreras, J. F., Coelho, M. R., ... Oliveira, J. B. de. (2018). Sistema brasileiro de classificação de solos (5th ed., V. 5, p. 356). Brasília: Embrapa.

Santos, R. D., Lemos, R. C., Santos, H. G., Ker, J. C., Anjos, L. H. C., \& Shimizu, S. H. (2015). Manual de descrição e coleta de solo no campo (7th ed., p. 100). Viçosa: SBCS.

Sekhar, C. C., Naidu, M. V. S., Ramprakash, T., \& Balaguravaiah, D. (2019). Genesis, characterization and classification of soils from selected parts of Prakasam district in Andhra Pradesh, India. Journal of Pharmacognosy and Phytochemistry, 8(1), 51-58. https://doi.org/10.22271/phyto

Silveira, M. M. L., Bezerra, A., M. S., De Sá, B. S., \& Valadares, E. (2006). Distribuição de fósforo em diferentes ordens de solo do semi-árido da Paraíba e de Pernambuco. Revista Brasileira de Ciência do Solo, 30(2), 281-291. https://doi.org/10.1590/S0100-06832006000200009

Soil Survey Staff. (2014). Keys to Soil Taxonomy (12th ed.). USDA-Natural Resources Conservation Service, Washington, DC.

Teixeira, P. C., Donagema, G. K., Fontana, A. \& Teixeira, W. G. (2017). Manual de Métodos de Análise de Solo (3rd ed., p. 574). Rio de Janeiro: Embrapa Solos.

Yeomans, J. C., \& Bremner, J. M. (1988). A rapid and precise method for routine determination of organic carbon in soil. Communications in Soil Science and Plant Analysis, 19(13), 1467-1476. https://doi.org/ $10.1080 / 00103628809368027$

\section{Copyrights}

Copyright for this article is retained by the author(s), with first publication rights granted to the journal.

This is an open-access article distributed under the terms and conditions of the Creative Commons Attribution license (http://creativecommons.org/licenses/by/4.0/). 